\title{
The Efficacy of the Bioecological Model of Human Development in Predicting Primary Pupils' Academic Achievement in Ghana and Its Curriculum Implications
}

\author{
Nyatsikor Maxwell Kwesi ${ }^{1}$, Esia-Donkoh Kweku ${ }^{2}$, Abroampa Winston Kwame, ${ }^{3, *}$ \\ ${ }^{1}$ Faculty of Education, University for Development Studies, Tamale, Ghana \\ ${ }^{2}$ Faculty of Educational Studies, University of Education, Winneba, Winneba, Ghana \\ ${ }^{3}$ Faculty of Educational Studies, Kwame Nkrumah University of Science and Technology, Kumasi, Ghana
}

\author{
Email address: \\ wynxtin@yahoo.com (A. W. Kwame) \\ *Corresponding author
}

\section{To cite this article:}

Nyatsikor Maxwell Kwesi, Esia-Donkoh Kweku, Abroampa Winston Kwame. The Efficacy of the Bioecological Model of Human Development in Predicting Primary Pupils' Academic Achievement in Ghana and Its Curriculum Implications. International Journal of Elementary Education. Vol. 8, No. 2, 2020, pp. 20-29. doi: 10.11648/j.ijeedu.20200902.11

Received: May 7, 2020; Accepted: May 26, 2020; Published: June 3, 2020

\begin{abstract}
The study examined the efficacy of the Bioecological Model of Human Development to predict Ghanaian primary school pupils' academic achievement in a National Education Assessment test in English language and mathematics. A total of 19,458 primary 3 and 17,447 primary 6 pupils from 548 schools were involved in the study. Participating schools were selected using stratified random sampling. Using a hierarchical multiple regression with a significance criterion at $p<0.001$, pupils' academic achievement was found to be significantly influenced by their personal characteristics, as well as the micro and macro environments they interacted in. Consistent with the theoretical model, pupils' microsystems contributed most to their levels of academic achievement. Moreover, the impact of pupils' personal characteristics on their academic achievement was moderated by the types of micro and macro systems they operated in. The outcome of the study validates the model's proposition that none of the variables operates in isolation but are mutually dependent in determining the levels of pupils' academic achievement in a given context. It is therefore suggested curriculum developers and education policy formulators to be guided by the model in attempts to initiate interventions to address the problem of low academic achievement among primary school pupils' in Ghana.
\end{abstract}

Keywords: Bioecological Model, Academic Achievement, Curriculum

\section{Introduction}

The interest in learning and learning outcomes at different levels of education has facilitated the development of various learning models (e.g. [1-3] and theories (see [4, 5]). These models and theories attempt to attribute the amount and quality of learning and learning outcomes to different factors and variables though there appears to be a consensus on specific factors as core influences $([6,2,7])$. The utility and applicability of these theories with their associated limitations have been explored through several studies in different contexts using different sample characteristics particularly from the western and more developed world ([8, $9,10])$. The application of the theories and models in different contexts to assess their generalizability is in acknowledgement of the role contextual factors play in validating existing and developing theories in education ([11, 10]). In this connection, the authors of this study share the view of others that any framework used to analyse how systems and schools function must consider local contexts ([12-15]). This is essential because different countries exhibit diverse political, geographical, social, economic, demographic and cultural contexts.

None of the papers reviewed for this current study focused on the utility of the Bioecological Model of Human Development in the African and Ghanaian context in particular (e.g. [10, 11]). One wonders, therefore, whether the applicability of the model in the largely western and more 
developed contexts can be generalized to the contextsensitive low-income country like Ghana with diverse cultural heritages and traditions. Driven by this uncertainty and gap in knowledge, this study examines the extent the Bioecological Model of Human Development developed by Urie Bronfenbrenner is able to predict and explain pupils' learning outcomes using a national education assessment data However, due to the limited information available in the dataset the study relied on, we examine only aspects of the contributions of "personal", "microsystem" and "macrosystem" variables to pupils' learning outcomes.

The Bioecological Model of Human Development examines the process of human development taking into account the larger context within which individuals learn ([1]). The model proposes that development takes place through processes of progressively more complex interaction between an active child and the persons, objects and symbols in their immediate environment ([16]). A core proposition of the model is that development always occurs in a particular social context and the context in turn influences the quality of development. Thus, to optimize their genetic potential, humans need to optimally develop the social contexts in which they operate $([1,16])$. For development outcomes (e.g. learning outcomes) to be maximized and effective a series of interaction (proximal processes) must occur on a fairly regular basis over extended periods of time [1]. However, the form, power, content, and direction of the proximal processes vary systematically as a joint function of the biological characteristics (e.g. intelligence level and age) of the developing person and the environment (e.g. home, school, and community) in which the processes are taking place ([17]). The essence and operation of the model is captured in four elements namely: (i) Process (ii) Person (iii) Context (microsystem, mesosystem, exosystem, and macrosystem) and; (iv) Time (chronosystem) ([1, 18]).

With this model the proximal process constitutes the core theme that explains the connection between some aspects of the context (e.g. social class) of the individual (e.g. pupils' gender and age) and an outcome of interest (e.g. learning outcomes) ([19]). It involves processes of progressively more complex reciprocal interaction between an active, evolving bio-psychological human organism and the persons, objects and symbols in their immediate external environment ([18]). Activities in homes demonstrating proximal processes include parents' engagement of children in playful yet educative activities and child to child activities such as drawing, counting and reading. In schools and classrooms, the quality of teacher-pupil interactions, pupil-pupil interactions and interactions with teaching and learning materials constitute proximal processes. The theory points out that the characteristics of the developing person (e.g. disposition, ability, knowledge, experience, skill, age) have a direct impact on both the quantity and the quality of proximal processes.

According to the theory, the personal characteristics (e.g. IQ level, health, gender, age) individuals bring with them into any social situation influence their levels of achievement or outcomes of interest ([20]). According to Bronfenbrenner [1] individuals possess attributes that invite, inhibit, or prevent engagement in sustained, progressively more complex interaction in the immediate environment. The theory categorizes personal attributes into demand, resource and force characteristics ([16]). Demand characteristics are those that act as immediate stimuli and include variables such as age and gender. These characteristics influence initial interactions between an individual and others in a given social setting such as the school. Resource characteristics relate partly to mental and emotional resources such as past experiences, skills, and intelligence as well as social and material resources (e.g. access to good food, housing, caring parents, educational opportunities appropriate to the needs of the particular society). The third personal characteristic embodies constructs such as temperament, motivation, and persistence. Differences in the levels of these constructs initiate, and to a large extent, sustain differences in outcomes of interest including pupils' academic achievements. For instance, two children may have equal resource characteristics (e.g. educational opportunities) but their developmental trajectories will be quite different if their levels of motivation and persistence to succeed significantly differ ([21]).

The theory suggests that in many societies, the differential treatment of boys and girls in the course of socialisation tends to communicate different role expectations and abilities to either gender as suggested by some studies ([22, 23]). Evidence suggests that some parents and teachers use a number of variables (including cultural, social, and gender) to form certain expectations for children who quickly grasp the messages and react accordingly regardless of their actual abilities. As a consequence, children begin to see themselves as bright or slow in specific subjects, or as individuals of whom much or less is expected $([24,25,26])$. Internationally, studies have consistently flagged that girls have significant advantage in literacy over boys from an early age $([15,27,28$, $29,30])$. On the contrary, boys are perceived to have advantage over girls in mathematics achievement. However, evidence suggests that boys generally receive more attention from teachers and dominate in the use of equipment in science, technology and computer studies than girls ([31, 32, $33,34])$. Generally, boys are reinforced for intellectual pursuits and girls for nurturing activities while attributing failure in boys to lack of motivation, and girls as lacking ability $([35,36,26])$.

The relationship between pupils' age and their cognitive or intellectual abilities has been proven theoretically and empirically. Theoretically, [37] theory of cognitive development and [38] socio-cultural theory reinforce the interplay between age and cognitive capabilities of children. The Bioecological Model of Human Development suggests the level of psychomotor, cognitive and affective tasks and accomplishments expected of persons are a function of their age. However, the theory does not discount the impact of the socio-economic status (SES) of children on the quantity and quality of proximal processes regardless of their gender and 
age. The superiority of children's SES to their personal characteristics (e.g. gender and age) has been established from many studies. For instance, [39] cites a PISA report which notes that a disadvantaged student, on average, scores 88 points lower on PISA reading tests than a socioeconomically-advantaged student. This difference represents more than two years of schooling. Moreover, the report cites that in the UK and elsewhere the influence of SES on learning outcomes is sometimes greater than that of gender ([40]). In the African context, the Southern African Consortium Monitoring of Educational Quality III (2007) regional assessment of students in Southern and East Africa also showed that household disadvantage strongly affected both reading and mathematics scores $([41,42,43])$.

The theory singles out the microsystem as the most significant sphere and refers to any environment such as home (family), school, or peer group in which the developing person spends a good deal of time engaging in activities and interactions ([20]). It is in the microsystem that the most direct interactions with social agents such parents (including other household members), teachers, peers and playmates in school and neighbourhood take place ([44]). According to [45] relationships at this level of interaction is bi-directional. For example, in the school, teachers influence the child through their actions and behaviours and the child also influences the teacher through their personal characteristics, experiences and feedback.

The mesosystem is a system of microsystems. It focuses on the connections between two or more different microsystems or contexts, such as the home, playground, and school ([1, 46]). An instance is when teachers (school microsystem) and parents (home microsystem) effectively collaborate and complement the effort of each other in the learning process of a child ([1]). The theory suggests that when parents attend school meetings or visit periodically to learn at first-hand about the strengths and weaknesses of their children, they will be in a better position to find effective ways to support them at home.

The exosystem contains both micro and meso systems and impacts the wellbeing of all those who come into contact with the child. It encompasses the linkage and processes taking place between two or more settings, at least one of which does not ordinarily contain the developing person, but in which events occur that influence processes within the immediate settings containing the person $([1,17])$. In this instance, the child does not directly encounter the system, but it impacts his or her development positively or negatively because the structures in this layer interact with some structures in the child's microsystem ([1, 17]). Parents' workplace schedules or community-based family resources are two examples that explain the influence of exosystem on both meso-and micro systems. For instance, where a parent's work schedule does not permit him or her to attend parentteacher meetings, the parent will have limited interaction with the teachers, thereby negatively influencing the effectiveness of the mesosystem.

The theory describes the macrosystem as a psychological environment encompassing the overall societal culture in which individuals live and its influence penetrating through all the other lower level layers ([16]). It encompasses any group whose members share values or belief systems, resources, hazards, lifestyles, opportunity structures, life course options and patterns of social interchange ([1, 21]). The macrosystem stipulates that for any particular value system to have any influence on a developing person it has to be experienced within one or more of the microsystems in which that person is situated. In this study, the localities (rural and urban) and regions from which schools were sampled served as two levels of macrosystems moderating the impact of school (microsystem) and pupil (person) characteristics.

The characteristics of macrosystems such as countries and demographic subgroups within countries (e.g. rural and urban communities) have been linked to academic achievement gaps in Ghana and elsewhere ([47, 48, 15, 49]). Using PISA data, Meyer and Schiller (n.d) cited in [15] found that pupils' learning outcomes varied with established socio-economic and cultural measures of participating countries. In Ghana, there is unequal levels of development across the various regions from which schools and pupils were sampled. The southernmost parts (e.g. Greater Accra and Western Regions) are more developed (i.e. better educational, industrial and economic opportunities) than the northernmost regions (e.g. Northern and Upper West Regions).

The final element of the theoretical model is time and it encompasses various aspects such as chronological age, duration and nature of periodicity as it relates to a child's environment. The theory proposes that elements within this system can be either external, such as the timing of a parent's death, or internal, such as the physiological changes that occur with the aging of a child ([17]). As children get older, they react differently to environmental changes and are able to determine how that change will influence them. From the fore review of the theoretical model, achievement of outcomes of interest is understood to be predicted by the quantity and quality of interactions, the personal characteristics of actors in a given context, and time. However, sight is not lost of the fact that different contexts and societies equally have different sets of educational and socialisation processes, beliefs and cultures which may determine the degree of applicability of this theory in those diverse settings. Given that this theory was exclusively developed in the context of the western world, the current study seeks to examine its relevance and validity in a nonwestern context such as Ghana. The following research questions guided the study.

To what extent do pupils' personal characteristics predict their achievement in English language and mathematics?

To what extent are pupils' achievement in English language and mathematics predicted by their microsystem?

How much of variance in English language and mathematics achievement can be explained by pupils' macrosystem? 


\section{Method}

The study population comprised primary school pupils from all the 16 regions in Ghana (currently there are 16 regions following the demarcation of certain regions) though the target population was primary grades $3(\mathrm{P} 3)$ and $6(\mathrm{P} 6)$ pupils. A total of 19,458 P3 and 17,447 P6 pupils from 548 schools were involved in the study. Participating schools were selected using stratified random sampling. Schools were stratified by region and sorted by district, locality (urban or rural), school type (public or private), and finally enrolment size. A total of 55 schools were randomly sampled with equal probability from each region except Ashanti and Northern regions where 54 schools each were selected because a school from each of these 2 regions was not in session at the time of administering the test. Alpha values of 0.89 and 0.84 were achieved respectively for P6 mathematics and English language tests while 0.82 and 0.84 were obtained for P3 mathematics and English language tests. According to the GNEA (2013) technical report, all scripts of participating pupils were duly returned ensuring a $100 \%$ return rate.

\subsection{Variables}

\subsubsection{Independent Variables}

Two variables explored under personal characteristics are pupils' gender and age. According to the Bioecological
Model of Human Development, the personal characteristics (e.g. gender, age) individuals bring with them into any social situation may influence their levels of achievement of outcomes of interest such as school work. The differential treatment of children based on their gender and age is thought to influence their perceptions of abilities and achievements in specific school subjects.

Microsystem variables explored are the schools and sizes of class children interacted in. It is in the microsystem that the most direct interactions with social agents such parents (including other household members), teachers, peers and playmates in school and neighbourhood take place. The theory suggests the microsystem is the most significant environment or setting for children's development.

Macrosystem variables investigated are the entire regions (national) and localities (rural, urban, and indeterminate) from which schools were sampled. According to the Bioecological Model of Human Development, this system encompasses any group whose members share values or belief systems, resources, hazards, lifestyles, opportunity structures, life course options and patterns of social interchange. Children's achievement are thought to be influenced by the resources, hazards and opportunities within defined macrosystems. The distributions of personal, microsystem and macrosystem variables are presented in Table 1.

Table 1. Descriptive information about of personal, microsystem and macrosystem variables.

\begin{tabular}{|c|c|c|c|c|c|c|c|c|c|c|c|}
\hline \multirow{2}{*}{\multicolumn{2}{|c|}{ Variables }} & \multicolumn{4}{|c|}{ Personal characteristics } & \multirow{2}{*}{\multicolumn{3}{|c|}{$\begin{array}{c}\text { Microsystem } \\
\text { School type (\% of pupils) }\end{array}$}} & \multirow{2}{*}{\multicolumn{3}{|c|}{$\begin{array}{c}\text { Macrosystem } \\
\text { School location (\% of pupils) }\end{array}$}} \\
\hline & & \multicolumn{2}{|c|}{ Gender (\%) } & \multicolumn{2}{|c|}{ Age (mean) } & & & & & & \\
\hline Region & $\begin{array}{l}\text { Total sample } \\
\text { size }\end{array}$ & Male & Female & Public & Private & $\begin{array}{l}\text { Class size } \\
\text { (mean) }\end{array}$ & Public & Private & Urban & Rural & Unclassified $^{1}$ \\
\hline \multicolumn{12}{|l|}{ Primary 3} \\
\hline Ashante & 1,787 & 52.3 & 47.7 & 10.7 & 9.6 & 10.4 & 75.1 & 24.9 & 34.9 & 50.4 & 14.8 \\
\hline Brong Ahafo & 2,045 & 51.6 & 48.4 & 11.0 & 9.9 & 10.8 & 82.7 & 17.3 & 37.2 & 50.5 & 12.3 \\
\hline Central & 1,462 & 51.9 & 48.1 & 10.7 & 9.6 & 10.5 & 78.9 & 21.1 & 16.7 & 59.2 & 24.1 \\
\hline Gt. Accra & 2,224 & 46.8 & 53.2 & 10.9 & 9.2 & 10.3 & 63.0 & 37.0 & 56.2 & 20.3 & 23.5 \\
\hline Northern & 1,661 & 55.2 & 44.8 & 10.7 & 10.7 & 10.7 & 93.3 & 6.7 & 24.5 & 70.6 & 4.9 \\
\hline Upper East & 2,690 & 53.8 & 46.2 & 11.0 & 9.9 & 10.9 & 91.4 & 8.6 & 7.0 & 86.6 & 6.4 \\
\hline Upper West & 2,489 & 48.7 & 51.3 & 11.4 & 9.8 & 11.3 & 94.0 & 6.0 & 11.1 & 75.7 & 13.3 \\
\hline Volta & 1,782 & 53.1 & 46.9 & 11.4 & 10.1 & 11.1 & 80.4 & 19.6 & 16.5 & 72.7 & 10.8 \\
\hline Western & 1,583 & 52.2 & 47.8 & 11.0 & 10.2 & 10.8 & 76.8 & 23.2 & 14.7 & 63.2 & 22.2 \\
\hline Total & 19,458 & 51.6 & 48.4 & 11.0 & 9.7 & 10.7 & 81.8 & 18.2 & 23.0 & 62.4 & 14.6 \\
\hline Brong Ahafo & 1,792 & 50.8 & 49.2 & 13.6 & 13.0 & 56.8 & 81.8 & 18.2 & 38.6 & 49.9 & 11.5 \\
\hline Central & 1,466 & 53.8 & 46.2 & 13.6 & 12.7 & 36.9 & 80.2 & 19.8 & 18.8 & 55.7 & 25.5 \\
\hline Eastern & 1,559 & 51.9 & 48.1 & 13.7 & 12.7 & 39.7 & 77.2 & 22.8 & 12.8 & 68.4 & 18.7 \\
\hline Gt. Accra & 2,145 & 46.5 & 53.5 & 13.5 & 12.2 & 54.6 & 61.9 & 38.1 & 60.1 & 17.2 & 22.7 \\
\hline Northern & 1,521 & 55.9 & 44.1 & 13.7 & 13.7 & 49.4 & 96.7 & 3.3 & 27.7 & 67.8 & 4.5 \\
\hline Upper East & 2,246 & 51.1 & 48.9 & 14.1 & 12.9 & 58.2 & 92.2 & 7.8 & 8.9 & 84.3 & 6.8 \\
\hline Upper West & 2,128 & 49.7 & 50.3 & 14.2 & 12.7 & 59.1 & 93.6 & 6.4 & 13.9 & 73.6 & 12.5 \\
\hline Volta & 1,609 & 52.6 & 47.4 & 14.1 & 13.2 & 42.1 & 78.4 & 21.6 & 15.4 & 74.5 & 10.2 \\
\hline Western & 1,426 & 52.7 & 47.3 & 13.5 & 12.8 & 36.2 & 74.8 & 25.2 & 15.1 & 58.8 & 26.1 \\
\hline Total & 17,447 & 51.3 & 48.7 & 51.3 & 48.7 & 48.9 & 81.5 & 18.5 & 25.3 & 59.4 & 15.3 \\
\hline
\end{tabular}

${ }^{l}$ at the time of collecting the data, some localities were yet to be designated as either rural or urban by the Government of Ghana (GNEA, 2013).

\subsubsection{Dependent Variables}

The dependent variables are English language and mathematics achievement scores for Ghanaian P3 and P6 pupils in a National Education Assessment test conducted in 2013. The mean achievement of pupils by gender, school type and school location are presented in Table 2. 
Table 2. Mean achievement of pupils by gender, school type and school location.

\begin{tabular}{|c|c|c|c|c|c|c|c|}
\hline \multirow{3}{*}{ Subject/ Region } & \multirow{2}{*}{\multicolumn{2}{|c|}{$\begin{array}{c}\text { Person characteristics } \\
\text { Gender (mean achievement) }\end{array}$}} & \multirow{2}{*}{\multicolumn{2}{|c|}{$\begin{array}{c}\text { Microsystem } \\
\text { School type (mean achievement) }\end{array}$}} & \multirow{2}{*}{\multicolumn{3}{|c|}{$\begin{array}{c}\text { Macrosystem } \\
\text { School location (mean achievement) }\end{array}$}} \\
\hline & & & & & & & \\
\hline & Male & Female & Private & Public & Urban & Rural & Unclassified $^{1}$ \\
\hline \multicolumn{8}{|l|}{$P 3$} \\
\hline English language & 12.77 & 12.98 & 18.92 & 11.51 & 15.86 & 11.56 & 13.69 \\
\hline $\begin{array}{l}\text { Mathematics } \\
\text { P6 }\end{array}$ & 12.10 & 11.99 & 16.13 & 11.13 & 13.99 & 11.19 & 12.58 \\
\hline English language & 19.15 & 19.24 & 26.94 & 17.43 & 24.00 & 16.79 & 20.51 \\
\hline Mathematics & 15.43 & 14.89 & 18.32 & 14.45 & 17.07 & 14.25 & 15.56 \\
\hline
\end{tabular}

${ }^{l}$ at the time of collecting the data, some localities were yet to be designated as either rural or urban by the government of Ghana (GNEA, 2013).

From the data in Table 2, the mean mathematics achievement difference between primary 3 boys $[\mathrm{M}=12.10$; $\mathrm{SD}=5.36]$ and girls $[\mathrm{M}=11.99 ; \mathrm{SD}=5.44 ; t(19391)=1.41$, $\mathrm{p}=.16$, two tailed] was statistically insignificant. Likewise, the mean English language achievement difference for boys $[\mathrm{M}=12.77 ; \mathrm{SD}=6.35]$ and girls $[\mathrm{M}=12.98 ; \mathrm{SD}=6.56 ; t$ $(19221)=-2.23, \mathrm{p}=.03$, two tailed] was statistically insignificant. For the primary 6 data, there was a statistically significant difference in the mean mathematics achievement for boys $[\mathrm{M}=15.48 ; \mathrm{SD}=5.07]$ and girls $[\mathrm{M}=14.89 ; \mathrm{SD}=$ 4.94; $t(17428)=-7.21, \mathrm{p}=.00$, two tailed]. On the contrary, the mean English language achievement between boys $[\mathrm{M}=$ $19.15 ; \mathrm{SD}=8.58]$ and girls $[\mathrm{M}=19.24 ; \mathrm{SD}=8.70 ; t(17428)$ $=.62, \mathrm{p}=.54$, two tailed) was statistically insignificant.

The difference in mean mathematics achievement for P3 children who attended private schools $[\mathrm{M}=16.13 ; \mathrm{SD}=5.86]$ and public schools $[\mathrm{M}=11.51 ; \mathrm{SD}=5.50 ; t(4669)=47.40$, $\mathrm{p}=.00$, two-tailed] was statistically significant. The mean achievement difference in English language for children who attended private schools $[\mathrm{M}=18.92 ; \mathrm{SD}=6.91]$ and public schools $[\mathrm{M}=11.51 ; \mathrm{SD}=5.50 ; t(4589)=59.79, \mathrm{p}=.00$, two-tailed] was statistically significant. For P6 mathematics achievement, the difference in the mean score for children who attended private schools $[\mathrm{M}=18.32 ; \mathrm{SD}=5.37]$ and public schools $[\mathrm{M}=14.45 ; \mathrm{SD}=4.64 ; t(4374)=-37.892, \mathrm{p}$ $=.00$, two-tailed] was statistically significant. The mean achievement difference in English language for children who attended private schools $[\mathrm{M}=26.94 ; \mathrm{SD}=7.83]$ and public schools $[\mathrm{M}=17.43 ; \mathrm{SD}=7.81 ; t(17445)=-62.41, \mathrm{p}=.00$, two-tailed] was statistically significant.

One-way ANOVA test was applied to compare the mean achievements for pupils from rural, urban and unclassified localities. For the primary 3 sample, the mean mathematics achievement differences among rural $[\mathrm{M}=11.19 ; \mathrm{SD}=4.97]$, urban $[\mathrm{M}=13.99 ; \mathrm{SD}=5.91]$ and unclassified localities $[\mathrm{M}$ $=12.58 ; \mathrm{SD}=5.44 ; F(2,19455)=483, \mathrm{p}=.00$, two tailed $]$ were statistically significant. Similarly, the mean English language achievement differences for rural $[\mathrm{M}=11.56 ; \mathrm{SD}=$ 5.64], urban $[\mathrm{M}=15.86 ; \mathrm{SD}=7.25]$ and unclassified localities $[\mathrm{M}=13.69 ; \mathrm{SD}=6.65 ; F(2,19455)=818, \mathrm{p}=.00$, two tailed] were statistically significant. For the primary 6 sample, the mean mathematics achievement differences among rural $[\mathrm{M}=14.25 ; \mathrm{SD}=4.67]$, urban $[\mathrm{M}=17.07$; $\mathrm{SD}$ $=5.28]$ and unclassified localities $[\mathrm{M}=15.56 ; S D=4.94 ; F$ $(2,17444)=528, \mathrm{p}=.00$, two tailed] were statistically significant. Similarly, the mean English language achievement difference for rural $[\mathrm{M}=16.79$; $\mathrm{SD}=7.51]$, urban $[\mathrm{M}=24.00 ; \mathrm{SD}=8.88]$ and unclassified localities $[\mathrm{M}$ $=20.51 ; \mathrm{SD}=8.70 ; F(2,17444)=1278, \mathrm{p}=.00$, two tailed $]$ were statistically significant.

\subsection{Data Analysis Procedure}

The data was analysed using hierarchical (sequential) regression to find how well the personal, micro and macro system characteristics are able to predict pupils' learning outcomes. Preliminary analyses were conducted to ensure no violation of the assumptions of normality, linearity, multicollinearity and homoscedasticity. The independent variables were entered into the model based on the concepts of the theory under examination. Sequentially, person (gender and age), microsystem (school and class size) and macrosystem (school location and region) variables were entered in the model as $2^{\text {nd }}, 3^{\text {rd }}$ and $4^{\text {th }}$ blocks respectively after controlling for district type as block 1 . The results obtained for the two subjects at both grade levels are presented from Tables 3 to 6 .

Table 3. Hierarchical multiple regression for P3 English language achievement.

\begin{tabular}{|c|c|c|c|c|c|c|c|}
\hline \multirow{2}{*}{ Independent Variables } & \multicolumn{2}{|c|}{ Standardized Coefficients } & \multirow{2}{*}{$\begin{array}{l}\text { Correlation coefficients } \\
\text { (part) }\end{array}$} & \multirow{2}{*}{$\%$ explained } & \multirow{2}{*}{$\mathbf{R}^{2}$} & \multirow{2}{*}{$R^{2}$ change } & \multirow{2}{*}{$\begin{array}{l}\% \text { in } R^{2} \\
\text { change }\end{array}$} \\
\hline & Beta & Sig. & & & & & \\
\hline \multicolumn{8}{|l|}{ Controlled variables } \\
\hline District type & -.262 & .000 & -.262 & 6.86 & .068 & .068 & - \\
\hline \multicolumn{8}{|l|}{ Personal variables } \\
\hline Pupils gender & -.007 & 167 & -.007 & 0.00 & \multirow{2}{*}{.104} & \multirow{2}{*}{.036} & \multirow{2}{*}{3.6} \\
\hline Pupil age & -.191 & .000 & -.189 & 3.57 & & & \\
\hline \multicolumn{8}{|l|}{ Microsystem variables } \\
\hline School & .383 & .000 & .360 & 12.96 & \multirow{2}{*}{.238} & \multirow{2}{*}{.134} & \multirow{2}{*}{13.4} \\
\hline Class size & .085 & .000 & .085 & 0.72 & & & \\
\hline
\end{tabular}




\begin{tabular}{|c|c|c|c|c|c|c|c|}
\hline \multirow{2}{*}{ Independent Variables } & \multicolumn{2}{|c|}{ Standardized Coefficients } & \multirow{2}{*}{$\begin{array}{l}\text { Correlation coefficients } \\
\text { (part) }\end{array}$} & \multirow{2}{*}{$\%$ explained } & \multirow{2}{*}{$\mathbf{R}^{2}$} & \multirow{2}{*}{$\mathbf{R}^{2}$ change } & \multirow{2}{*}{$\begin{array}{l}\% \text { in } R^{2} \\
\text { change }\end{array}$} \\
\hline & Beta & Sig. & & & & & \\
\hline $\begin{array}{l}\text { School location } \\
\text { Region }\end{array}$ & $\begin{array}{l}.067 \\
-.052\end{array}$ & $\begin{array}{l}.000 \\
.000\end{array}$ & $\begin{array}{l}.062 \\
-.048\end{array}$ & $\begin{array}{l}0.38 \\
0.49\end{array}$ & .245 & .007 & 0.7 \\
\hline
\end{tabular}

Table 4. Hierarchical multiple regression for P3 mathematics achievement.

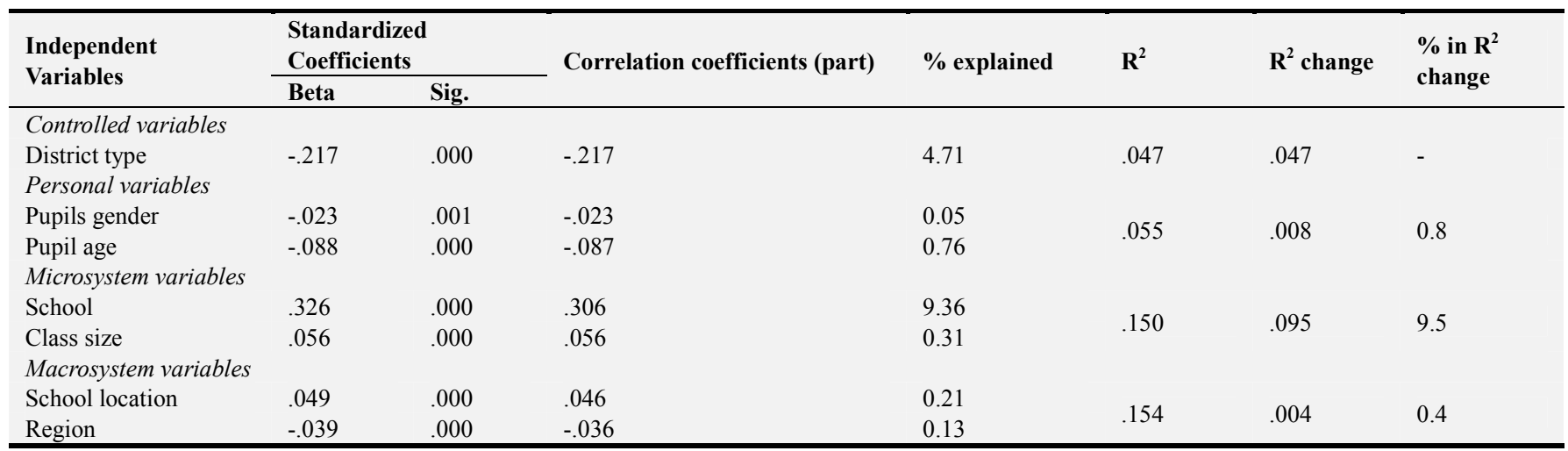

Table 5. Hierarchical multiple regression for P6 English language achievement.

\begin{tabular}{|c|c|c|c|c|c|c|c|}
\hline \multirow{2}{*}{$\begin{array}{l}\text { Independent } \\
\text { Variables }\end{array}$} & \multicolumn{2}{|c|}{$\begin{array}{l}\text { Standardized } \\
\text { Coefficients }\end{array}$} & \multirow{2}{*}{$\begin{array}{l}\text { Correlation coefficients } \\
\text { (part) }\end{array}$} & \multirow[t]{2}{*}{$\%$ explained } & \multirow[t]{2}{*}{$\mathbf{R}^{2}$} & \multirow[t]{2}{*}{$\mathbf{R}^{2}$ change } & \multirow{2}{*}{$\begin{array}{l}\% \text { in } R^{2} \\
\text { change }\end{array}$} \\
\hline & Beta & Sig. & & & & & \\
\hline \multicolumn{8}{|c|}{ Controlled variables } \\
\hline $\begin{array}{l}\text { District type } \\
\text { Personal variabl }\end{array}$ & -.313 & .000 & -.313 & 9.80 & .098 & .098 & - \\
\hline $\begin{array}{l}\text { Pupils gender } \\
\text { Pupil age }\end{array}$ & $\begin{array}{l}-.028 \\
-.247\end{array}$ & $\begin{array}{l}.000 \\
000\end{array}$ & $\begin{array}{l}-.028 \\
-.243\end{array}$ & $\begin{array}{l}0.08 \\
5.90\end{array}$ & \multirow[t]{2}{*}{.157} & \multirow[t]{2}{*}{.059} & \multirow[t]{2}{*}{5.9} \\
\hline Microsystem vari & & & & & & & \\
\hline $\begin{array}{l}\text { School } \\
\text { Class size }\end{array}$ & $\begin{array}{l}.304 \\
.178\end{array}$ & $\begin{array}{l}.000 \\
.000\end{array}$ & $\begin{array}{l}.286 \\
.178\end{array}$ & $\begin{array}{l}8.18 \\
3.17\end{array}$ & \multirow[t]{2}{*}{.284} & \multirow[t]{2}{*}{.127} & \multirow[t]{2}{*}{12.7} \\
\hline Macrosystem var & & & & & & & \\
\hline $\begin{array}{l}\text { School location } \\
\text { Region }\end{array}$ & $\begin{array}{l}.244 \\
.045\end{array}$ & $\begin{array}{l}.000 \\
.000\end{array}$ & $\begin{array}{l}.208 \\
.042\end{array}$ & $\begin{array}{l}4.33 \\
0.18\end{array}$ & .327 & .044 & 4.3 \\
\hline
\end{tabular}

Table 6. Hierarchical multiple regression for P6 mathematics achievement.

\begin{tabular}{|c|c|c|c|c|c|c|c|}
\hline \multirow{2}{*}{$\begin{array}{l}\text { Independent } \\
\text { Variables } \\
\end{array}$} & \multicolumn{2}{|c|}{ Standardized Coefficients } & \multirow{2}{*}{$\begin{array}{l}\text { Correlation coefficients } \\
\text { (part) }\end{array}$} & \multirow{2}{*}{$\%$ explained } & \multirow{2}{*}{$\mathbf{R}^{2}$} & \multirow{2}{*}{$\mathbf{R}^{2}$ change } & \multirow{2}{*}{$\begin{array}{l}\% \text { in } R^{2} \\
\text { change }\end{array}$} \\
\hline & Beta & Sig. & & & & & \\
\hline \multicolumn{8}{|c|}{ Controlled variables } \\
\hline $\begin{array}{l}\text { District type } \\
\text { Personal variabl }\end{array}$ & -.217 & .000 & -.217 & 4.70 & .047 & .047 & - \\
\hline Pupils gender & -.078 & .000 & -.077 & 0.59 & \multirow{2}{*}{.082} & \multirow{2}{*}{.034} & \multirow{2}{*}{3.4} \\
\hline $\begin{array}{l}\text { Pupil age } \\
\text { Microsystem var }\end{array}$ & -.178 & .000 & -.175 & 3.06 & & & \\
\hline $\begin{array}{l}\text { School } \\
\text { Class size }\end{array}$ & $\begin{array}{l}.230 \\
.116\end{array}$ & $\begin{array}{l}.000 \\
.000\end{array}$ & $\begin{array}{l}.215 \\
.116\end{array}$ & $\begin{array}{l}4.62 \\
1.35\end{array}$ & \multirow[t]{2}{*}{.142} & \multirow[t]{2}{*}{.060} & \multirow[t]{2}{*}{6.0} \\
\hline Macrosystem var & & & & & & & \\
\hline $\begin{array}{l}\text { School location } \\
\text { Region }\end{array}$ & $\begin{array}{l}.159 \\
.020\end{array}$ & $\begin{array}{l}.000 \\
.012\end{array}$ & $\begin{array}{l}.135 \\
.019\end{array}$ & $\begin{array}{l}1.82 \\
0.04\end{array}$ & .160 & .018 & 1.8 \\
\hline
\end{tabular}

\section{Results}

The results indicated that pupils' learning outcomes were predicted by aspects of their personal, micro and macro system characteristics. Each of the variables made a statistically significant contribution to pupils learning outcomes at $p<.001$ except gender (P3 English language achievement) and region (P6 mathematics achievement). For P3 English language achievement, the ANOVA table indicated that the model as a whole (including all blocks of variables) was significant $(\mathrm{F}(7,19315)=893.68, p<.001)$. The model for P3 mathematics achievement from all the blocks of variables was also significant $(F(7,19315)=$ $500.87, p<.001)$. For P6 English language achievement, the ANOVA table indicated that the model as a whole was significant $(\mathrm{F}(7,14749)=1025.99, p<.001)$. The statistics for P6 mathematics achievement also indicated that the model from all the blocks of variables was significant ( F ( 7 , $14749)=402.50, p<.001)$.

Person, microsystem and macrosystem variables respectively predicted $3.6 \%, 13.4 \%$ and $0.7 \%$ of the variances 
in P3 English language achievement. Similarly, person, microsystem and macrosystem variables respectively predicted $0.8 \%, 9.5 \%$ and $0.4 \%$ of the variances in $\mathrm{P} 3$ mathematics achievement. For the P6 sample, person, microsystem and macrosystem variables respectively predicted 5.9\%, 12.7\% and $4.3 \%$ of the variances in English language achievement. Correspondingly, person, microsystem and macrosystem variables predicted $3.4 \%, 6.0 \%$ and $1.8 \%$ of the variances in P6 mathematics achievement. Consistently, the results revealed that the contributions from pupils' microsystem was largest for both subjects and grade levels. Schools made the strongest unique contribution to explaining achievement levels in both subjects at grade levels when the variance explained by all other variables in the model was controlled for. The degree of impact of personal characteristics and macrosystem varied across school subjects and grade levels. For instance, personal characteristics of children made the most impact (5.9\%) on P6 English language achievement and least $(0.8 \%)$ on P3 mathematics achievement. The impact of pupils' macrosystem was largest (4.3\%) for P6 English language achievement and least $(0.4 \%)$ for P3 mathematics achievement. The variations in the levels of impact of personal characteristics, micro and macro systems on pupils' achievement signals that the effect of specific variables are moderated, to an extent, by the operation of others. Though most of the variables made statistically significant contributions to achievement, not all are of practical significance as evidenced by the share of the percentage explained of the dependent variable attributed to specific variables. Typical examples are the impacts of pupils' gender and regions which were consistently less than $1 \%$ across both subjects and grade levels. Pupils' age made both statistical and practical significance to achievement variances across subjects and grade levels.

\section{Discussion}

Consistent with the theory, pupils' characteristics (age and gender) predicted their levels of achievement to a certain degree. However, gender was not a good predictor of variances in achievement in school subjects in general. There are more similarities in achievement between genders than differences as evidenced by the t-test analysis. The triviality of pupils' gender to predict achievement appears to contest the theory's position that outcomes of interests are genderdependent. Nonetheless, this finding is comprehensible. Increasingly, boys and girls are being socialized in ways that offer them equal teaching and learning opportunities both at home and schools as required by national and international policies and goals ([50, 51, 52, 22]). Specifically, SDG 4 mandates countries to provide equal learning opportunities for all children regardless of gender. It may be the case therefore, that significant gender differences in achievement may be the result of variations in ethno-cultural characteristics and other context-specific factors ([53]). These ethno-cultural and context specific factors include the expectations and roles expected of male and female population of a country and not necessarily sex-specific capabilities (or lack thereof) in school subjects.

Pupils' age contributed significantly to achievement in both subjects and grade levels. The negative impact of pupils' age on achievement in both subjects suggested that on average, relatively younger children outperformed the relatively older pupils. As evidenced in Tables 1 and 2, the mean achievements of the averagely younger children from private schools were significantly higher than those from the averagely older children from public schools. Available evidence across different contexts suggest that private schools are better resourced and supervised than public schools $([54,55])$. The availability and effective use of these educational and social resources by pupils from private schools (which promote quality proximal processes) mitigate the disadvantages associated with their younger age or "Piagetian" abilities. Consistent with the theory, pupils' age predicted learning outcomes but its predictive power was influenced by quantity and quality of other factors particularly within their microsystems.

The microsystem children interacted in was found to be the most important predictor of achievement in school subjects as evidenced by the unique contribution of schools. Unambiguously, the theory posits that the microsystem (e.g. school) is the most significant environment in which the developing person spends a good deal of time engaging in activities and interactions $([20,1])$. The consistency of the microsystem (with emphasis on schools) as the most important environment gives credence to the notion that in Ghana and other countries in Sub-Sahara Africa, schools contribute most to pupils' learning outcomes than other pupil and community characteristics $([43,56,6])$. The finding suggests that when schools are adequately resourced and teaching and learning activities effectively supervised, they can significantly offset some of the personal and household socio-economic disadvantages children bring to school ([6]). It behoves governments, schools and teachers to provide stable, friendly and productive school climates that benefit all children from diverse backgrounds as proposed by national and international policies and protocols ([22, 50]).

The macrosystem also contributed to pupils' learning outcomes by serving as psychological environments in which schools (microsystem) and pupils (person) operated. Although not of practical significance, yet the negative impact of regions on P3 English language and mathematics achievement suggested that some prevailing conditions in the regions were not conducive for effective teaching and learning. In other contexts (emphasis P6 English language) macrosystem variables predicted approximately $4 \%$ of the variances in achievement recorded. Cumulatively, the unequal dynamics of socio-economic, educational and cultural values within specific regions and localities influenced pupils' learning and learning outcomes at varying degrees. This is true to the extent that the economic development and employment opportunities in specific geographical areas (e.g. available employment opportunities) directly have impact on the SES of parents which correspondingly affect the welfare of children. Consistent 
with prior study findings (e.g. $[15,42,56]$ ), the results confirm that pupils' academic achievements can be predicted by the characteristics of the country or geographical location from which they are sampled. It is incumbent on government and educators to create congenial psychological environment within entire educational metropolises, municipals and districts for effective teaching and learning to flourish in schools and homes.

\section{Conclusion}

The study examined the effectiveness of the Bioecological Model of Human Development to predict primary school pupils' achievement in a National Education Assessment test in Ghana. The characteristics of persons (e.g. gender and age), microsystem (schools and class size) and macrosystem (school localities and regions) predicted achievement in school subjects at varying degrees. Cumulatively, the 6 independent variables predicted $17.7 \%$ and $10.7 \%$ of the variances in P3 English language and mathematics achievement respectively while $22.9 \%$ and $11.3 \%$ of the variances in P6 English language and mathematics achievement were predicted by the same number of independent variables. Differences in pupils' gender was not of practical importance for the variances in achievement in both subjects under focus and any differences may be due to variations in ethno-cultural characteristics and other contextspecific factors. Nonetheless, all children regardless of gender and socio-economic backgrounds, should be given equal opportunities to teaching and learning activities. Likewise, the chronological age of pupils was not a sufficient guarantee for school success but it is rather influenced by what goes on in their microsystems (e.g. schools) and their socio-economic backgrounds (e.g. school location). It is therefore recommended that children are sent to schools at the right age while at the same time providing them with the required resources to support effective teaching and learning.

Interactions within children's microsystem significantly mattered for their achievement levels in school subjects which, without a glitch, aligns with the theory under focus. It is therefore imperative that teachers, parents, guardians and stakeholders provide optimum opportunities at schools and homes to facilitate effective teaching and learning at all times. Ensuring this will not only improve school performance but also create better opportunities for pupils to develop their potentials for personal and national development. Moreover, resourcing school communities with the required educational and social amenities is proven to favourably predict children's learning outcomes. Consistent with the theoretical model, the results suggested that variables linked to persons, schools and localities actually predict pupils' academic achievement at different levels of statistical and practical importance. Critically, the percentage contributions from each of the variables examined provides empirical evidence to stakeholders in identifying critical areas to consider in finding solutions to the persistent abysmal academic achievement among primary school children.

\section{Recommendations}

The findings from the study provide strong evidence of the relevance of the theoretical model for curriculum development and implementation in the Ghanaian context. Learner characteristics and environmental dynamics are critical determinants of curriculum making. Since learners are considered as the final consumers of any educational programme and the reason for its construction, such programmes must be constructed taking into consideration learner characteristics and the systems or the home, school and larger societal environments within which they operate. It is thus expected that any productive curriculum development venture commences with a robust situational analysis activity which critically assesses learner, teacher and environmental factors that may impinge on teaching and learning or have implications for curriculum enactment. Undertaking this exercise will facilitate the initiation of measures or interventions to mitigate any negative effects on the learner or facilitate interactions that would ultimately promote learner outcomes on the other hand.

In this regard, policies aimed at improving the quantity and quality of teaching and learning in schools must be prioritized. Guided by this study and model, educational policy makers, teachers, parents and learners should be brought up to speed on the crucial roles the dynamics in the socio-cultural environment in the home and school play in promoting learning and influencing learning outcomes.

\section{Acknowledgements}

The authors are grateful to USAID and RTI International (the primary owners of the dataset) for the permission to use the Ghana National Education Assessment data for this research publication. The authors assume all risk of using the data and any results or conclusions obtained through such use.

\section{References}

[1] Bronfenbrenner, U., (2005). Making human beings human: Bioecological perspectives on human development. Thousand Oaks, CA: Sage.

[2] Creemers, B. P. M. \& Kyriakides, L. (2012). Improving quality in education: Dynamic approaches to school improvement, London, UK: Routledge.

[3] Kaya, Z, \& Akdemir, S. (Eds). (2016). Learning and teaching theories, approaches and models $\left(2^{\text {nd }}\right.$ ed). Çözüm Eğitim Yayıncılık. Ankara, Türkiye.

[4] Zhou, M. \& Brown, D. (2015). Educational Learning Theories (2nd ed). GALILEO Open Learning Materials.

[5] Bates, B. (2019). Learning theories simplified. SAGE Publications Ltd. London.

[6] Hattie, J., (2009). Visible learning: A synthesis of over 800 meta-analyses relating to achievement. London/New York: Routledge. 
[7] Burroughs, N., Gardner, J., Lee, Y, Guo, S., Touitou, I., Jansen, K., et al. (2019). Teaching for Excellence and Equity Analyzing Teacher Characteristics, Behaviours and Student Outcomes with TIMSS. International Association for the Evaluation of Educational Achievement (IEA) https://doi.org/10.1007/978-3-030-16151-4_1

[8] Hirsto, L. (2001). Children in their learning environments: theoretical perspectives. Unit of Educational Psychology Research Reports 5/2001. University of Helsinki.

[9] Creemers, B. P. M, Kyriakides, L. and Sammons, P. (2010). Methodological advances in educational effectiveness research. Routledge.

[10] Lewthwaite, B. (Ed) (2011). Manitoba Education Research Network (MERN) Monograph Series Issue 4, Spring 2011.

[11] Johnson, E. S. (2008). Ecological Systems and Complexity Theory: Toward an Alternative Model of Accountability in Education. Complicity: An International Journal of Complexity and Education, 5 (1) pp. 1-10.

[12] Crossley, M., (2014). Global league tables, big data and the international transfer of educational research modalities. Comparative Education, 50 (1), pp. 15-26, doi: 10.1080/03050068.2013.871438.

[13] Lavy, V., (2012). Expanding school resources and increasing time on task: effects of a policy experiment in Israel on student academic achievement and behaviour. Working Paper. Coventry, UK: Department of Economics, University of Warwick. (CAGE Online Working Paper Series).

[14] Barber, M. and Mourshed, M., (2007). How the world's bestperforming school systems come out on top. McKinsey and Company. London.

[15] Meyer, H. \& Benavot, A., (Eds) (2013). PISA, power, and policy: The emergence of global educational governance. Oxford Studies in Comparative Education. UK. Symposium books.

[16] Bronfenbrenner, U. \& Morris, P. A., (1998). The ecology of development processes. In W. Damon (Series Ed.) \& R. M. Lerner (Vol. Ed.), Handbook of child psychology: Vol. 1. Theoretical models of human development (pp. 993-1027). New York, NY: Wiley.

[17] Bronfenbrenner, U. \& Morris, P. A., (2006). The bioecological model of human development. In W. Damon (Series Ed.) \& R. M. Lerner (Vol. Ed.), Handbook of child psychology: Theoretical models of human development (pp. 793-828). New York, NY: Wiley.

[18] Bronfenbrenner, U. and Evans, G. W., (2000). Developmental science in the 21 st century: Emerging theoretical models, research designs, and empirical findings. Social Development, 9 , pp. 115-125.

[19] Bronfenbrenner, U. \& Crouter, A. C., (1983). The evolution of environmental models in developmental research. In Paul $\mathrm{H}$. Mussen Ed.), Handbook of child psychology (4th ed.) pp. 357-414. Toronto, ON: John Wiley \& Sons.

[20] Bronfenbrenner, U. (2001). The bioecological theory of human development. In N. J. Smelser \& P. B. Baltes (Eds.), International encyclopaedia of the social and behavioural sciences, pp. 6963-6970. Oxford, UK: Elsevier.

[21] Tudge, J. R. H., Mokrova, I. L., Hatfield, B. E., and Karnik, R.
B. (2009). Uses and misuses of Bronfenbrenner's bioecological theory of human development. Journal of Family Theory and Review, 1, pp. 198-210.

[22] UNESCO, (2019a). Meeting Commitments Are Countries on Track to Achieve SDG 4? UNESCO Institute for Statistics.

[23] Endendijk, J. J., Groeneveld, M. G., Bakermans-Kranenburg, M. J., Mesman, J. (2016). Gender Differentiated Parenting Revisited: Meta-Analysis Reveals Very Few Differences in Parental Control of Boys and Girls. PLoSONE11 (7): e0159193. doi: 10.1371/journal.pone.0159193

[24] Reilly, D., Neumann, D. L., \& Andrews, G. (2019). Gender Differences in Reading and Writing Achievement: Evidence from the National Assessment of Educational Progress (NAEP). American Psychologist, 74, (4), pp 445-458. http://dx.doi.org/10.1037/amp0000356

[25] Mujtaba, T., and Reiss, M. J., (2012). What sort of girl wants to study physics after the age of 16 ? Findings from a largescale UK survey. International Journal of Science Education, pp. 1-20, iFirst Article.

[26] UNESCO. 2019b. Global Education Monitoring Report Gender Report: Building bridges for gender equality. Paris, UNESCO.

[27] Martin, M. O., Mullis, I. V. S., \& Foy, P. (2012). PIRLS 2011 International Report: IEA's Progress in International Reading Literacy Study in Primary School. Chestnut Hill, MA: Boston College. http://timssandpirls.bc.edu/isc/publications.html

[28] Marc Jackman, W., Morrain-Webb, J. \& Fuller, C. (Reviewing editor) (2019). Exploring gender differences in achievement through student voice: Critical insights and analyses, Cogent Education, 6: 1, 1567895

[29] Organisation for Economic Co-operation and Development [OECD] (2018). Gender Gap in Educational Outcomes in Norway. Education Working Paper No. 183.

[30] Evans, D. K., Akmal, M., Jakiela, P. (2019). Gender Gaps in Education: The Long View. CGD Working Paper 523. Center for Global Development. https://www.cgdev.org/publication/gender-gaps-educationlong-view

[31] Kemp, P. E. J \& Berry, M. G. (2019). Female Performance and Participation in Computer Science: A National Picture. ACM Trans. Comput. Educ. 20, 1,(4), 28 pages. https://doi.org/10.1145/3366016

[32] Royal Society (2017). After the reboot: Computing education in UK schools. The Royal Society, London

[33] Vitores, A. \& Gil-Juárez, A. (2016). The trouble with "women in computing": A critical examination of the deployment of research on the gender gap in computer science. Journal of Gender Studies 25, 6 (2016), 666-680. DOI: https://doi.org/10.1080/09589236.2015.1087309

[34] Wong, B. \& Kemp, P. E. J. (2018). Technical boys and creative girls: The career aspirations of digitally skilled youths. Cambridge Journal of Education 48, (3), pp. 301-316.

[35] UNESCO, (2017). Cracking the code: Girls' and women's education in science, technology, engineering and mathematics (STEM) 
[36] Ceci, S. J., and W. M. Williams. 2011. "Understanding Current Causes of Women's Underrepresentation in Science." Proceedings of the National Academy of Sciences 108 (8): $3157-3162$.

http://www.pnas.org/content/108/8/3157.full10.1073/pnas.101 4871108 [Google Scholar]

[37] Piaget, J., (1970). Science of education and the psychology of the child. New York: Orion Press.

[38] Vygotsky, L., (1978). Mind in society: The development of higher psychological processes. Cambridge, MA: Harvard University Press.

[39] Upton, P. \& Taylor, C. E., (2014). Educational psychology. Pearson Education Ltd. UK.

[40] Francis, B., Luk-Fog, P. Y. and Skelton, C., (2012). Gender and achievement in the UK and Hong Kong. In C. Forlin (Ed), Future Directions for Inclusive Teacher Education: An international perspective (pp. 131-140). Abingdon: Taylor and Francis.

[41] Hungi, N., Makuwa, D., Ross, K., Saito, M., Dolata, S., Van Cappelle, F. and Vellien, J., (2010b). SACMEQ III Project Result: Pupil achievement levels in reading and mathematics. Working Document Number 1 SACMEQ.

[42] Hungi, N., (2011b). Characteristics of grade 6 pupils, their homes and learning Environments. SACMEQ working paper 1. Available: http://www.sacmeq.org/sites/default/files/sacmeq/publications /01_pupils_final_24nov 2011.pdf. Date Accessed: 05/04/20.

[43] Bashir, S., Lockheed, M., Ninan, E. \& Tan, J-P (2018). Facing Forward Schooling for Learning in Africa. International Bank for Reconstruction and Development/The World Bank.

[44] Saarinen, P., Ruoppila, I. \& Korkiakangas, M. (1994). Kasvatuspsykologian kysymyksiä. Helsingin yliopisto: Lahden koulutus- ja tutkimuskeskus. [Problems in Educational Psychology. University of Helsinki: Lahti's Centrum of Education and Research]

[45] Bronfenbrenner, U. (2000). Ecological systems theory. In A. Kazdin (Ed.), Encyclopaedia of Psychology, (Vol. 3,) pp. 129133. Washington, DC: American Psychological Association.
[46] Christensen, J. (2010). Proposed Enhancement of Bronfenbrenner's Development Ecology Model. Education Inquiry, 1 (2), pp. 101-110.

[47] Ghana National Educational Assessment Technical Report (2013). (May 2014). Ministry of Education. Accra.

[48] Ghana National Educational Assessment Technical Report (2016). Ministry of Education. Accra.

[49] Chiu, M. M., \& Chow, B. W-Y. (2015). International Comparisons of Student Achievement. In: Roberta V. Nata (Ed) Progress in Education. 32. Nova Science Publishers, Inc.

[50] Ministry of Education (2015). Inclusive education policy in Ghana. Accra: MoE.

[51] National Teacher Education Curriculum Framework. (2017). MoE. Accra: Ghana.

[52] United Nations, (2015). Helping governments and stakeholders make sustainable development goals a reality. United Nations. New York.

[53] Dalley-Trim, L., (2007). The boys' present...hegemonic masculinity: a performance of multiple acts. Gender and education, 19 (2). pp. 199-217. Allen and Unwin.

[54] Tooley, J., \& Longfield, D., (2014). The Role and Impact of Private Schools in Developing Countries: A Response to DFID's "Rigorous Literature Review". E. G. West Centre, Newcastle University. UK.

[55] Day Ashley, L., C. Mcloughlin, M. Aslam, J. Engel, J. Wales, S. Rawal, R. Batley, G. Kingdon, S. Nicolai, \&P. Rose. (2014). The Role and Impact of Private Schools in Developing Countries: A Rigorous Review of the Evidence.” EPPI-Centre Report No. 2206, Education Rigorous Literature Review commissioned by the U.K. Department for International Development (DFID), London.

[56] UNESCO, (2018). Learning at the bottom of the pyramid: Science, measurement, and policy in low income countries. International Institute for Educational Planning. UNESCO. 